\title{
STUDI KEMAMPUAN BERKARYA SENI RUPA TEKNIK TEMPEL PADA SISWA KELAS IV SEKOLAH DASAR
}

\author{
Dhera Andhini Rachmawati* \\ Sumanto \\ Puri Selfi Cholifah \\ Pendidikan Guru Sekolah Dasar, Jurusan KSDP, Fakultas Ilmu Pendidikan, Universitas Negeri Malang \\ Jalan Semarang No 5, Malang, Indonesia \\ *E-mail: andhinidhera@gmail.com
}

Artikel diterima: 27 Maret 2020; disetujui: 30 November 2020

\begin{abstract}
This research aims to describe the ability to work on art paste techniques of class IV students in cluster 3 Elementary School of Junrejo, Batu. They are viewed from creativity, skills and aesthetics, especially in mosaic art, collage art, and montage art. This research used a mix-method with the type of research using sequential explanatory analysis. Practice tests, surveys, observation, interview, and documentation are used in this research. The result of the study shows that most students working on paste techniques includes good categories. Besides, the inhibiting factors and supporters mostly come from students themselves, the completeness of tools and materials, and the environment.
\end{abstract}

Keywords: art work ability; mosaic; collage; montage

\begin{abstract}
Abstrak: Tujuan Penelitian ini adalah mendeskripsikan kemampuan berkarya seni rupa teknik tempel siswa kelas IV di SDN se-gugus 3 Kecamatan Junrejo Kota Batu. Dilihat dari aspek kreativitas, keterampilan, dan keindahan khususnya pada berkarya seni mozaik, seni kolase, dan seni montase. Pendekatan yang digunakan yaitu mix-method (penelitian kombinasi) dengan jenis penelitian menggunakan metode urutan pembuktian (sequential explanatory). Data dikumpulkan menggunakan tes praktik, survey, observasi, wawancara, kuisoner, dan dokumentasi. Hasil dari penelitian ini menunjukkan bahwa sebagian besar siswa dalam berkarya seni rupa termasuk kategori baik. Selain itu faktor penghambat dan pendukungnya terdapat dari siswa itu sendiri, kelengkapan alat dan bahan, serta lingkungan.
\end{abstract}

Kata kunci: kemampuan berkarya seni; mozaik; kolase; montase

\section{PENDAHULUAN}

Seni rupa adalah cabang seni yang menggunakan segala sesuatu yang berwujud nyata sehingga dapat dilihat dan memiliki unsur titik, garis, bentuk/bangun, warna, tekstur, isi, ruang, dan cahaya (Fauzi dkk., 2019; Kustilawati, 2013). Karya seni rupa terbagi menjadi dua, yaitu dua dimensi dan tiga dimensi (Putro, 2017). Salah satu karya seni dua dimensi yaitu seni rupa teknik tempel yang terdiri dari seni mozaik, seni, kolase, dan seni montase (Fauziddin, 2018). Berkarya seni rupa teknik tempel dapat dilihat dari segi kemampuan. Kemampuan berkarya seni rupa teknik 
tempel dapat dilihat dari segi kreativitas, keterampilan, dan keindahan (Hasnawati \& Anggraini, 2016; Nelson \& Pd, 2016; Yuningsih, 2019). Kreativitas yang dimiliki setiap siswa berbeda-beda dalam berimajinasi. Selain berhubungan dengan kreativitas seni juga berhubungan dengan keterampilan, dapat dikatakan bahwa keterampilan bagian dari proses penciptaan karya seni rupa (Wahana, 2019). Keindahan, salah satu rasa yang berhubungan dengan setiap manusia. Setiap manusia mampu menangkap atau merasakan keindahan yang ada di sekitarnya (Sutrisno, 2005).

Setiap anak memiliki tingkat kreativitasnya masing-masing dalam berimajinasi. Kreativitas diartikan sebagai kemampuan untuk menciptakan sesuatu yang baru dan dapat meningkatkan status kuo pengetahuan (Zaidel, 2014). Pendapat lain kreativitas lebih menyoroti masalah komponen kreativitas yaitu terkait kebaruan, keberfungsian, kecerdasan, dan arti itu sendiri (Sääksjärvi \& Gonçalves, 2018). Setiap manusia memiliki kualitas kreatif yang berbeda-beda dan kreativitas dimiliki setiap manusia yang menjadikan karakteristik dari manusia itu sendiri.

Selain berhubungan dengan kreativitas, seni juga berhubungan dengan keterampilan. Apabila kreativitas merupakan bagian dari kegiatan berkarya, maka keterampilan merupakan bagian dari proses penciptaan karya seni rupa. Keterkaitan karya seni dengan aspek perbuatan manusia sebagai kemahiran, kegiatan manusia, karya seni, keindahan, dan penglihatan (Kustiawan dkk., 2018).

Keindahan, salah satu rasa yang berhubungan dengan setiap manusia, baik berupa keindahan alam maupun keindahan karya manusia. Secara luas pengertian keindahan meliputi seni,alam, moral, dan intelektual, sedangkan pengertian keindahan dalam arti terbatas hanya menyangkut benda-benda yang dapat dilihat yakni keindahan bentuk dan warna secara kasat mata (Dharsono \& Nanang, 2004). Setiap manusia mampu menangkap atau merasakan keindahan yang ada di sekitarnya.

Salah satu kegiatan karya seni rupa teknik tempel berada di kelas IV. Hal ini berdasarkan peraturan peraturan Menteri Pendidikan dan Kebudayaan Republik Indonesia Nomor 37 Tahun 2018 Lampiran 30 terdapat KD 3.4 Mengetahui karya seni rupa teknik tempel dan KD 4.4 Membuat karya kolase, montase, aplikasi dan mozaik (Kemdikbud, 2018). Terdapat pada buku tematik Tema 6 Cita-citaku, dan Tema 7 Indahnya Keragaman Negriku. Penelitian ini dilaksanakan di kelas IV, dimana siswa sudah berusia 10 tahun. Masa kanak-kanak dibagi menjadi dua fase (Jannah, 2015), yaitu (a) masa kelas rendah sekolah dasar yang berlangsung antara 6-7 tahun sampai 9-10 tahun, biasanya siswa duduk di kelas 1, 2, dan 3 sekolah dasar, dan (b) masa kelas tinggi sekolah dasar yang berlangsung antara 9-10 tahun sampai 12-13 tahun. Pada usia tersebut mulai memperlihatkan kreativitas berupa karya seni. Sikap dan perilaku siswa pada saat mengikuti kegiatan berolah seni ada yang sama atau berbeda. Hal tersebut dilatar belakangi oleh adanya faktor pendukung dan penghambat dalam membuat karya seni. Faktor pendukung dan penghambat dapat berasal dari lingkungan, material, dan kepribadian siswa itu sendiri (Rahayu, 
2014). Kendala tersebut dapat diatasi dengan adanya perhatian dan pembinaan yang sungguhsungguh dari guru SD.

Pada pembelajaran seni rupa teknik tempel yang terdiri dari seni mozaik, kolase, montase, dan aplikasi, namun peneliti hanya mengambil seni mozaik, kolase, dan montase dikarenakan berdasarkan hasil wawancara kepada guru kelas IV di SDN se-gugus 3 pada semester genap siswa kelas IV tidak diajarkan seni aplikasi. Hal tersebut terjadi karena seni aplikasi dirasa sulit untuk siswa kelas IV dalam pembuatan karya seni. Peneliti ingin mendeskripsikan kemampuan siswa kelas IV di SDN se-gugus 3 Kecamatan Junrejo Kota Batu dalam berkarya seni rupa teknik tempel terutama pada seni mozaik, kolase, dan montase.

Berdasarkan hasil wawancara, hasil studi dokumen, dan kajian penelitian yang relevan mengenai kemampuan berkarya seni rupa teknik tempel maka penelitan ini layak untuk dilakukan. Berdasarkan hal tersebut, peneliti mengambil fokus masalah tentang kemampuan berkarya seni rupa teknik tempel terutama pada seni mozaik, kolase, dan montase pada siswa kelas IV dilihat dari aspek kreativitas, keterampilan, dan keindahan sebagai unsur kebaruan penelitian ini. Penelitian ini bertujuan untuk menganalisis dan mendeskripsikan tentang kemampuan berkarya seni rupa teknik tempel siswa melalui aspek kreativitas, keterampilan, dan keindahan. Selain itu juga untuk menggali faktor-faktor yang menjadi pendukung dan penghambat kemampuan siswa dalam berkarya seni rupa teknik tempel.

\section{METODE}

Penelitian ini menggunakan pendekatan penelitian kombinasi (mix-method) yang menggabungkan pendekatan kuantitatif dan kualitatif. Dalam penelitian ini menggunakan metode urutan pembuktian (sequential explanatory) (Bowen dkk., 2017). Dalam penelitian ini, peneliti memperoleh data kuantitatif pada kemampuan berkarya seni rupa teknik tempel siswa kelas IV melalui tes praktik dan survei yang dilakukan kepada siswa kelas IV di SDN se-gugus 3 Kecamatan Junrejo Kota Batu. Tes praktik digunakan untuk menganalisis kemampuan siswa dalam berkarya seni rupa teknik tempel. Data tes yang digunakan berupa hasil karya siswa dalam berkarya seni rupa teknik tempel menggunakan rubrik penilaian berdasarkan aspek kreativitas, keterampilan, dan keindahan. Survei yang digunakan semi tertutup yang bertujuan untuk mengetahui faktor-faktor pendukung dan penghambat yang dialami siswa dalam berkarya seni rupa teknik tempel. Kisi-kisi kemampuan berkarya seni rupa teknik tempel siswa kelas IV disajikan pada Tabel 1.

Selanjutnya peneliti memperluas data kuantitatif yang diperoleh pada tahap awal melalui data kualitatif berupa observasi proses berkarya seni dan dokumentasi hasil karya seni yang dilakukan saat penelitian berlangsung. Selanjutnya melaksanakan wawancara yang dilakukan kepada siswa 
kelas IV secara purposive sampling serta guru wali kelas IV di SDN Se-gugus 3 Kecamatan Junrejo Kota Batu. Wawancara bertujuan untuk mencari informasi mengenai faktor pendukung dan faktor penghambat siswa dalam berkarya seni dan juga informasi yang terkait dalam kemampuan siswa dalam berkarya seni rupa teknik tempel. Melalui teknik ini, peneliti dapat menganalisis dan mendeskripsikan tentang kemampuan berkarya seni rupa teknik tempel siswa melalui aspek kreativitas, keterampilan, dan keindahan. Selain itu juga untuk menggali faktorfaktor yang menjadi pendukung dan penghambat kemampuan siswa dalam berkarya seni rupa teknik tempel. Pedoman penilaian hasil karya seni rupa teknik tempel dapat dilihat pada Tabel 2.

\section{Tabel 1 Kisi-kisi Kemampuan Berkarya Seni Rupa Teknik Tempel Siswa Kelas IV}

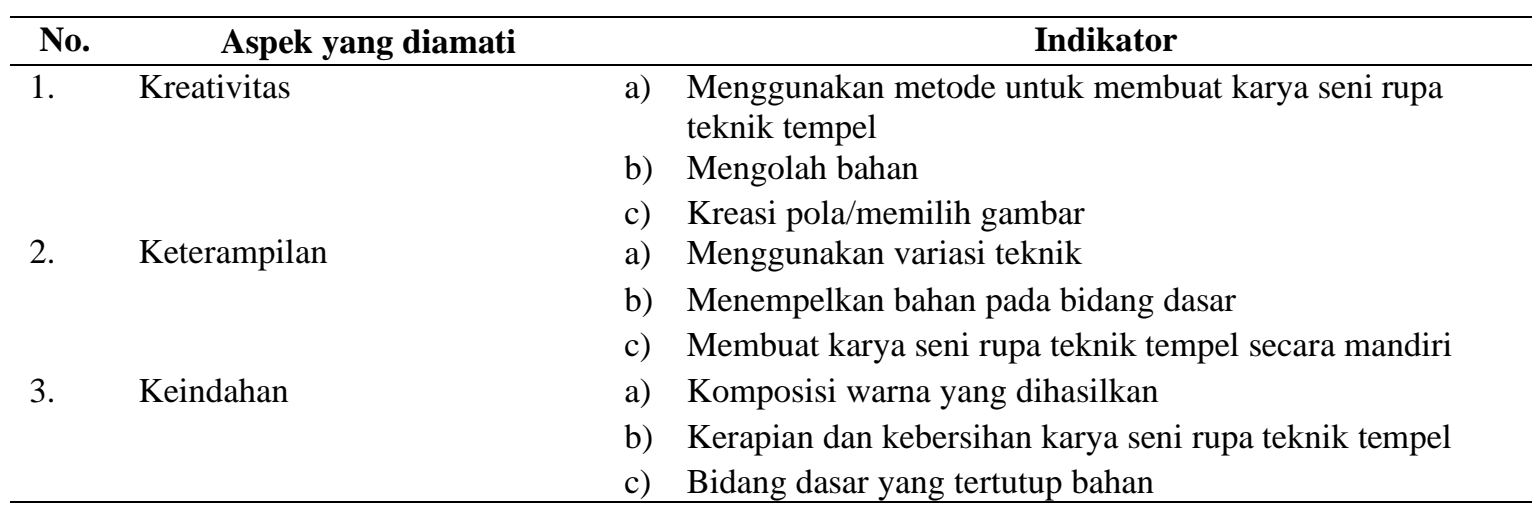

Sumber: modifikasi Eltanindya (2019)

Tabel 2 Pedoman Penilaian Hasil Karya Seni Rupa Teknik Tempel

\begin{tabular}{|c|c|c|}
\hline & Predikat & Rentang Skor (\%) \\
\hline 4 & Sangat Baik & $85-100$ \\
\hline 3 & Baik & $70-84$ \\
\hline 2 & Cukup & $55-69$ \\
\hline 1 & Kurang & $\leq 54$ \\
\hline
\end{tabular}

Sumber: modifikasi S. Rahayu (2017)

Tabel 3 Data Responden Siswa

\begin{tabular}{llc}
\hline & Sekolah & Jumlah Siswa \\
\hline 1 & SDN Pendem 01 Batu & 30 \\
2 & SDN Pendem 02 Batu & 35 \\
3 & SDN Dadaprejo 01 Batu & 27 \\
4 & SDN Dadaprejo 02 Batu & 20 \\
& Total & 112 \\
\hline
\end{tabular}

Data yang dikumpulkan dari penelitian ini yaitu (1) hasil karya seni rupa teknik tempel siswa kelas IV, (2) observasi proses berkarya seni rupa teknik tempel siswa kelas IV, (3) wawancara mengenai faktor pendukung dan faktor penghambat siswa dalam berkarya seni rupa teknik tempel, dan (4) informasi yang mendukung topik yang dibahas melalui instrumen berupa angket. Datadata tersebut akan diperkuat dengan dokumentasi. 
Subjek selaku sumber data yang terlibat pada penelitian ini yaitu siswa kelas IV di SDN segugus 3 Kecamatan Junrejo Kota Batu yang disajikan pada Tabel 3. Selain siswa, sumber data diperoleh dari guru kelas IV SDN se-gugus 3 Kecamatan Junrejo Kota Batu sebanyak 4 guru.

Teknik pengumpulan data pada penelitian ini menggunakan tes praktik, survei, wawancara, observasi, dan dokumentasi. Sedangkan analisis data dimulai dari pengumpulan data, reduksi data, penyajian data, dan penarikan kesimpulan. Keabsahan data dilakukan dengan triangulasi sumber dan metode.

\section{HASIL DAN PEMBAHASAN}

\section{Kemampuan Berkarya Seni Rupa Teknik Tempel dari Aspek Kreativitas}

Kemampuan berkarya seni rupa teknik tempel siswa dilihat dari aspek kreativitas dapat diketahui melalui observasi proses berkarya seni rupa teknik tempel. Rekapitulasi hasil karya siswa, dan dokumentasi. Kemampuan berkarya seni rupa teknik tempel pada siswa kelas IV di SDN se-gugus 3 Kecamatan Junrejo Kota Batu dilihat dari aspek kreativitas memiliki tiga indikator yaitu (1) menggunakan metode dalam berkarya seni rupa teknik tempel, (2) mengolah bahan, dan (3) kreasi pola/memilih gambar. Kemampuan berkarya seni mozaik, seni kolase, dan seni montase dilihat dari aspek kreativitas ditunjukkan pada Tabel 4.

Tabel 4 Rekapitulasi Nilai Rata-Rata Aspek Kreativitas

\begin{tabular}{|c|c|c|c|c|c|c|c|}
\hline \multirow{3}{*}{ No. } & \multirow{3}{*}{ Nama Sekolah } & \multicolumn{6}{|c|}{ Aspek Kreativitas } \\
\hline & & \multicolumn{2}{|c|}{ Seni Mozaik } & \multicolumn{2}{|c|}{ Seni Kolase } & \multicolumn{2}{|c|}{ Seni Montase } \\
\hline & & Nilai & Kategori & Nilai & Kategori & Nilai & Kategori \\
\hline 1 & SDN Dadaprejo 01 & 72 & Baik & 73 & Baik & 71 & Baik \\
\hline 2 & SDN Dadaprejo 02 & 68 & Cukup & 66 & Cukup & 67 & Cukup \\
\hline 3 & SDN Pendem 01 & 74 & Baik & 74 & Baik & 74 & Baik \\
\hline 4 & SDN Pendem 02 & 73 & Baik & 75 & Baik & 69 & Cukup \\
\hline \multicolumn{2}{|c|}{ Nilai Rata-rata } & 72 & Baik & 72 & Baik & 70 & Baik \\
\hline
\end{tabular}

Secara keseluruhan, kemampuan berkarya seni teknik tempel pada jenis seni mozaik, seni kolase, dan seni montase dalam kategori baik, meskipun di salah satu sekolah nilai rata-rata untuk ketiga teknik seni dalam ketgori cukup. Pada praktiknya siswa dibebaskan membawa bahan untuk kegiatan yang berlangsung seperti biji jagung, biji matahari, kacang hijau, beras merah, beras putih, kacang tanah, biji-bijian untuk makan burung, beras ketan, wijen, dan sebagainya. Siswa dalam membuat pola gambar dapat ditunjukkan pada Gambar 1. Metode yang digunakan sebagian kecil sudah menggunakan keempat metode yaitu penataan ruang, pengulangan, tumpang tindih, dan komposisi bahan. Namun sebagian besar siswa hanya menggunakan tiga sampai dua metode dari empat metode yang ada. 


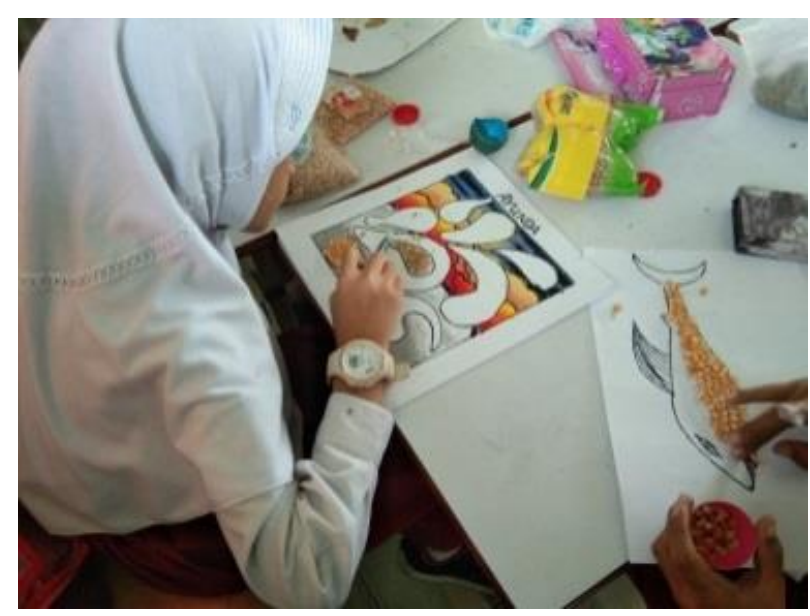

Gambar 1. Pola Gambar Pada Seni Mozaik

Pada pembuatan berkarya seni kolase sebagian besar siswa antusias dalam pembuatan pola gambar. Pada seni kolase, dalam pengolahan bahan, ada yang menggunting daun-daunan kering secara kecil-kecil namun ada juga yang menggunting daun-daunan kering sesuai dengan pola gambar. Pada saat membuat pola gambar, ada juga proses berkarya seni kolase tanpa menggambar pola terlebih dahulu. Metode yang digunakan sebagian kecil sudah menggunakan keempat metode yaitu penataan ruang, pengulangan, tumpang tindih, dan komposisi bahan. Namun sebagian besar siswa hanya menggunakan tiga sampai dua metode dari empat metode yang ada.

Pada pembuatan berkarya seni montase siswa sudah membawa alat dan bahan seperti majalah Bobo, gunting, alat pewarna, dan lem. Dalam pengolahan bahan, siswa memilih gambar yang terdapat pada majalah BoBo sesuai dengan tema yang dipilih setelah itu digunting sesuai dengan pola gamba. Namun ada juga yang menggunting tidak sesuai dengan pola gambar. Pada saat pemilihan gambar atau pemilihan tema, sebagian besar siswa memilih gambar atau tema yang lebih condong seperti cerita bergambar, namun ada juga yang memilih gambar sesuai dengan tema yang dipilih. Pemilihan gambar siswa cenderung seperti cerita bergambar dapat dilihat pada Gambar 2.

Kreativitas setiap siswa dapat menjadikan karya seni rupa teknik tempel yang dibuat menjadi lebih unik dan estetis dengan komposisi bahan-bahan yang menarik. Karya seni rupa teknik tempel ini menggunakan bahan dasar alam dan sintetis. Bahan dasar alam seperti biji-bijian dan cangkang telur digunakan untuk berkarya seni mozaik, sedangkan daun-daun kering digunakan untuk berkarya seni kolase. Bahan dasar sintetis yaitu majalah BoBo yang digunakan untuk berkarya seni montase. Kemampuan berkarya seni kolase dilihat dari aspek kreativitas memiliki tiga indikator yang perlu diperhatikan yaitu menggunakan metode untuk membuat karya seni rupa teknik tempel, mengolah bahan, dan kreasi pola/memilih gambar. Hal itu sesuai dengan pernyataan bahwa kreativitas adalah kemampuan berolah seni rupa yang diwujudkan dengan membuat motif di 
dasaran, memotong bahan yang akan di lemkan ke motif yang telah dibuat (Hasnawati \& Anggraini, 2016; Nelson \& Pd, 2016).

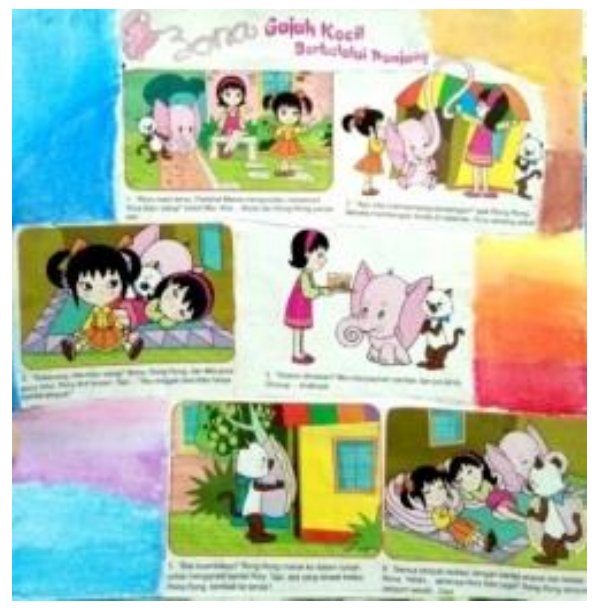

\section{Gambar 2. Penggunaan Gambar dari Buku Bacaan}

Kemampuan berkarya seni rupa teknik tempel siswa kelas IV di SDN se-gugus 3 Kecamatan Junrejo Kota Batu dari segi kreativitas tergolong baik dilihat dari penggunaan metode untuk membuat karya seni rupa teknik tempel, pengolahan bahan, dan kreasi pola/pemilihan gambar. Dari temuan penelitian ini, siswa sudah membawa bahan-bahan yang akan digunakan dalam berkarya seni rupa teknik tempel. Metode yang digunakan dalam berkarya seni rupa teknik tempel yaitu tumpang tindih atau saling tutup (overlapping), penataan ruang (spacial arrangement), pengulangan (repetition), dan komposisi bahan (Isnanta, 2015). Penggunaan metode untuk berkarya seni rupa teknik tempel dapat dipadukan antara metode yang satu dengan metode yang lainnya. Sedangkan pengolahan bahan untuk berkarya seni rupa teknik tempel beragam. Saat berkarya seni mozaik, ada beberapa bahan yang diolah seperti diwarnai namun ada juga tanpa adanya pengolahan. Bahan yang diwarnai seperti beras dan cangkang telur. Pengolahan bahan saat berkarya seni kolase, siswa memotong daun-daunan kering secara kecil-kecil namun ada juga yang memotong sesuai dengan pola gambar. Sedangkan untuk seni montase, siswa mengolah bahan dari majalah BoBo dengan cara memotong gambar sesuai dengan pola gambar namun ada juga yang memotong tidak sesuai dengan pola sehingga seni montase seperti cerita bergambar.

Pembuatan pola gambar pada karya seni mozaik dan kolase pada siswa kelas IV di SDN segugus 3 Kecamatan Junrejo Kota Batu ada yang unik dan baru meskipun ada yang membuat pola secara unik atau mencontoh dari gambar yang ada. Hal itu sejalan dengan pernyataan kreativitas merupakan kemampuan untuk mencipta yang memiliki kadar kreativitasnya seperti mencipta, menggubah, dan mencontoh (Sumanto dkk., 2014). Saat berkarya seni montase, siswa juga bebas dalam memilih tema yang diinginkan. Kebebasan siswa untuk bereksplorasi dalam proses pembelajaran dapat mengembangkan kreativitas. Sejalan dengan pernyataan bahwa melalui 
berkarya siswa dapat mengeksplorasi kemamouannya, serta dapat mengembangkan daya imjaniasi, daya khayal, sikap cekatan, telaten, dan kreatif (Munawara, 2016). Pembelajaran tanpa adanya paksaan, merasa bebas dan senang akan lebih efektif dalam mengembangkan kreativitas siswa.

\section{Kemampuan Berkarya Seni Rupa Teknik Tempel dari Aspek Keterampilan}

Kemampuan berkarya seni rupa teknik tempel pada siswa yang dilihat dari aspek keterampilan memiliki tiga indikator yaitu: (1) menggunakan variasi teknik, (2) menempelkan bahan pada bidang dasar, dan (3) berkarya seni rupa teknik tempel secara mandiri. Rekapitulasi nilai pada aspek keterampilan disajikan pada Tabel 5. Berdasarkan data dari Tabel 5 diketahui bahwa secara keseluruhan aspek keterampilan siswa dalam kategori baik.

Tabel 5 Rekapitulasi Nilai Rata-Rata Aspek Keterampilan

\begin{tabular}{|c|c|c|c|c|c|c|c|}
\hline \multirow{3}{*}{ No. } & \multirow{3}{*}{ Nama Sekolah } & \multicolumn{6}{|c|}{ Aspek Keterampilan } \\
\hline & & \multicolumn{2}{|c|}{ Seni Mozaik } & \multicolumn{2}{|c|}{ Seni Kolase } & \multicolumn{2}{|c|}{ Seni Montase } \\
\hline & & Nilai & Kategori & Nilai & Kategori & Nilai & Kategori \\
\hline 1 & SDN Dadaprejo 01 & 75 & Baik & 80 & Baik & 84 & Baik \\
\hline 2 & SDN Dadaprejo 02 & 75 & Baik & 79 & Baik & 83 & Baik \\
\hline 3 & SDN Pendem 01 & 77 & Baik & 79 & Baik & 85 & Baik \\
\hline 4 & SDN Pendem 02 & 78 & Baik & 83 & Baik & 83 & Baik \\
\hline \multicolumn{2}{|c|}{ Nilai Rata-rata } & 76 & Baik & 80 & Baik & 80 & Baik \\
\hline
\end{tabular}

Penggunaan variasi teknik pada berkarya seni mozaik secara keseluruhan siswa menggunakan teknik sobek dan teknik rekat. Teknik sobek digunakan untuk menyobek cangkang telur. Siswa sudah baik saat menempelkan biji-bijian dan cangkang telur pada bidang dasar namun masih ada biji-bijian dan cangkang telur yang terlepas dari bidang dasar karena pemberian lem yang kurang merata atau terlalu sedikit. Pada saat proses berkarya seni mozaik siswa membuat karya seni mozaik secara mandiri.

Penggunaan variasi teknik pada berkarya seni kolase sebagian kecil menggunakan tiga variasi teknik yaitu teknik potong, teknik sobek dan teknik rekat. Teknik sobek dan teknik potong digunakan untuk memotong daun-daunan kering. Siswa dalam menggunakan teknik sobek dapat dilihat pada Gambar 3. Siswa sudah baik saat menempelkan daun-daunan kering pada bidang dasar namun masih ada daun-daunan kering yang terlepas dari bidang dasar karena pemberian lem yang kurang merata atau terlalu sedikit.

Penggunaan variasi teknik pada berkarya seni mozaik secara keseluruhan siswa menggunakan teknik potong dan teknik rekat. Teknik potong digunakan untuk memotong gambar pada majalah BoBo. Sebagian besar siswa sudah baik saat menempelkan gambar pada bidang dasar, pemberian lem pada gambar sudah merata.

Membuat karya seni rupa teknik tempel sangat membutuhkan keterampilan seperti keterampilan dalam menempel, memadukan, menyusun, dan keterampilan lainnya. Untuk membuat karya seni rupa teknik tempel siswa dituntut untuk memiliki ketelitian, ketelatenan, dan 
kesabaran. Pada pembuatan karya seni rupa teknik tempel siswa kelas IV di SDN se-gugus 3 Kecamatan Junrejo Kota Batu ditinjau dari aspek keterampilan terdapat tiga indikator meliputi menggunakan variasi teknik dalam berkarya seni rupa teknik, menempelkan bahan pada bidang dasar, dan kemandirian siswa dalam membuat karya seni rupa teknik tempel.

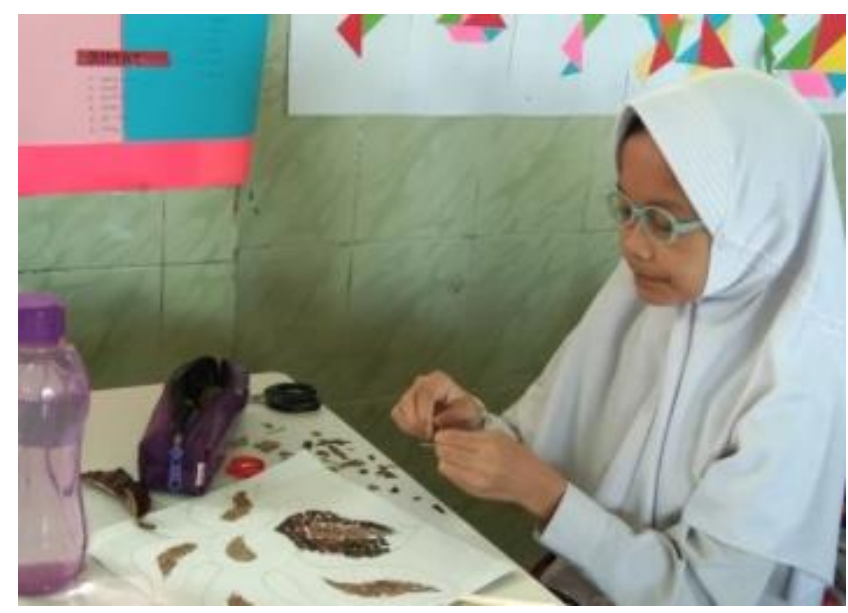

Gambar 3. Siswa Menggunakan Teknik Sobek Pada Kolase

Kemampuan berkarya seni rupa teknik tempel siswa kelas IV di SDN se-gugus 3 Kecamatan Junrejo Batu dari aspek keterampilan tergolong baik dilihat dari variasi teknik yang digunakan, penempelan bahan pada bidang dasar, dan pembuatan karya seni rupa teknik tempel dilakukan secara mandiri. Dari temuan penelitian ini, saat berkarya seni mozaik dan kolase siswa menggunakan beberapa variasi teknik seperti teknik potong, teknik sobek, dan teknik rekat sehingga variatif bentuk, ukuran, tekstur, dan jenis bahan yang bermacam-macam. Sedangkan untuk berkarya seni montase, siswa menggunakan variasi teknik potong dan teknik rekat. Siswa dalam memotong gambar untuk berkarya seni montase disesuaikan dengan pola gambar.

Bahan yang digunakan pada karya seni rupa teknik tempel berbeda-beda sehingga memerlukan lem yang sesuai dengan jenis bahan agar bahan tersebut dapat melekat dengan baik. Siswa dapat berpikir dan berkreasi untuk menghasilkan suatu karya yang baik dengan bahan yang ada (Yustiana, 2018). Agar karya seni rupa teknik tempel terlihat baik dan indah maka diperlukan keterampilan untuk merekatkan bahan dan perekat yang sesuai dengan jenis bahan. Pada penggunaan lem saat berkarya seni mozaik dan kolase siswa dalam memberikan lem pada bahan masih kurang merata sehingga beberapa karya masih ada bahan yang terlepas. Berdasarkan hasil kuisoner untuk berkarya seni mozaik 59\% siswa merasa kesulitan saat menempelkan bahan pada bidang dasar sedangkan untuk berkarya seni kolase 63\% siswa merasa kesulitan. Saat berkarya seni montase, penggunaan lem sudah merata. Berdasarkan hasil kuisoner, hanya $34 \%$ siswa merasa kesulitan saat menempelkan bahan pada bidang.

Pada saat membuat karya seni rupa teknik tempel siswa membuat dengan mandiri tanpa bantuan orang lain. Hal ini membuat keterampilan siswa dalam membuat karya seni rupa teknik 
tempel lebih terasah dan tidak bergantung dengan orang lain. Hal ini sesuai dengan pernyataan yang menyatakan bahwa sikap kemandirian seseorang pasti tidak sama, tetapi pentingnya sikap kemandirian ialah bahwa dalam menjalani hidupnya seseorang tidak terlalu dan tidak selalu bergantung pada orang lain (Mardeni, 2019). Lebih lanjut, kemandirian merupakan aspek dalam mengasah kemampuan yang dimiliki, dapat dipenuhi oleh individu yang mempunyai motivasi untuk berkarya dan mengelola emosi (Hidayati, 2014). Selain kemandirian merupakan kegiatan yang dilakukan tanpa bantuan orang lain, kemandirian juga termasuk salah satu aspek agar siswa memiliki motivasi dalam berkarya seni.

\section{Kemampuan Berkarya Seni Rupa Teknik Tempel dari Aspek Keindahan}

Kemampuan berkarya seni rupa teknik tempel pada siswa ditinjau dari aspek keindahan memiliki tiga indikator yaitu: (1) komposisi warna yang dihasilkan, (2) kerapian dan kebersihan karya seni rupa teknik tempel, dan (3) bidang dasar tertutup bahan. Rekapitulasi nilai pada aspek keindahan disajikan pada Tabel 6. Secara keseluruhan, kemampuan berkarya seni teknik tempel pada jenis seni mozaik, seni kolase, dan seni montase dalam kategori baik. Kategori cukup terbanyak pada seni mozaik yang nilai rata-rata cukup berada pada tiga sekolah, yang diikuti oleh satu sekolah dengan kategori cukup pada seni kolase.

Pewarnaan yang digunakan dalam berkarya seni mozaik berasal dari biji-bijian dan cangkang telur tidak diwarna namun ada juga yang diwarna, selain itu pewarnaan juga berasal dari alat pewarna yang dibawa. Masih ada beberapa siswa yang kurang dalam memadukan warna yang serasi. Meskipun begitu ada siswa yang pandai dalam memadukan warna yang serasi dari bahan dan alat pewarna yang dibawa. Untuk kerapian dan kebersihan karya seni mozaik sudah cukup baik namun masih tergantung tiap siswa. Siswa yang telaten dalam menempelkan bahan membuat karyanya menjadi rapi. Karya seni mozaik beberapa siswa secara keseluruhan bidang sudah tertutup dengan bahan dan adanya pewarnaan. Namun ada juga karya seni mozaik yang dibuat siswa sebagian besar masih kurang tertutup dengan bahan. Hal ini dikarenakan siswa cepat merasa bosan atau siswa ingin cepat selesai ketika melihat temannya yang selesai mengerjakan sehingga tidak menutup seluruh bidang dengan bahan.

Tabel 6 Rekapitulasi Nilai Rata-Rata Aspek Keindahan

\begin{tabular}{clcccccc}
\hline \multirow{2}{*}{ No. } & \multirow{2}{*}{ Nama Sekolah } & \multicolumn{5}{c}{ Aspek Keindahan } \\
\cline { 3 - 7 } & & \multicolumn{2}{c}{ Seni Mozaik } & \multicolumn{2}{c}{ Seni Kolase } & \multicolumn{2}{c}{ Seni Montase } \\
\cline { 2 - 7 } & Nilai & Kategori & Nilai & Kategori & Nilai & Kategori \\
\hline 1 & SDN Dadaprejo 01 & 68 & Cukup & 71 & Baik & 80 & Baik \\
2 & SDN Dadaprejo 02 & 63 & Cukup & 63 & Cukup & 83 & Baik \\
3 & SDN Pendem 01 & 71 & Baik & 77 & Baik & 77 & Baik \\
4 & SDN Pendem 02 & 70 & Baik & 79 & Baik & 78 & Baik \\
Nilai & Rata-rata & 68 & Cukup & 73 & Baik & 80 & Baik \\
\hline
\end{tabular}


Pewarnaan yang digunakan dalam berkarya seni kolase berasal dari daun-daunan kering, selain itu pewarnaan juga berasal dari alat pewarna yang dibawa. Masih ada beberapa siswa yang kurang dalam memadukan warna yang serasi. Siswa yang telaten dalam menempelkan bahan membuat karyanya menjadi rapi. Hasil karya seni siswa yang terlihat rapi dan bersih dapat dilihat pada Gambar 4. Pewarnaan yang digunakan dalam berkarya seni montase berasal gambar-gambar yang dipilih, selain itu pewarnaan juga berasal dari alat pewarna yang dibawa. Karya seni montase yang dibuat siswa sebagian besar sudah tertutup dengan bahan serta adanya pewarnaan, namun ada juga tanpa adanya pewarnaan Hal ini dikarenakan siswa cepat merasa bosan atau siswa ingin cepat selesai ketika melihat temannya yang selesai mengerjakan sehingga tidak menutup seluruh bidang dengan bahan.

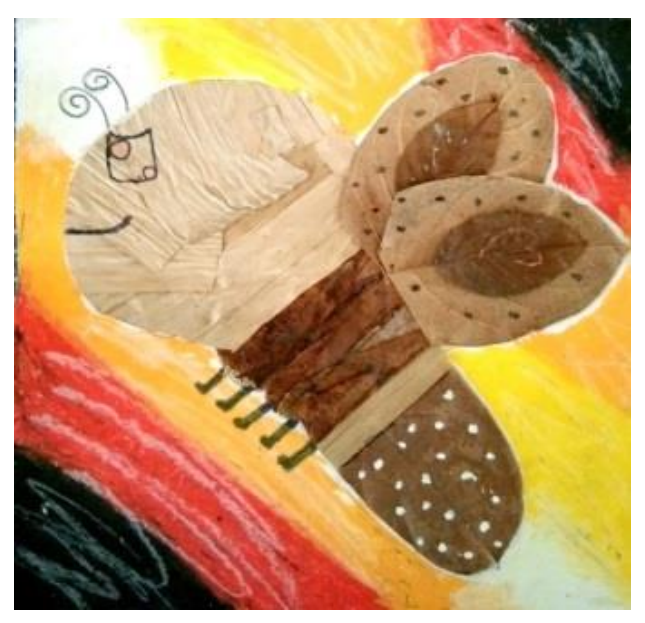

Gambar 4. Kebersihan Hasil Karya Seni Kolase

Karya seni rupa teknik tempel merupakan wujud karya untuk mengekspresikan nilai estetis. Menurut fungsinya karya seni rupa teknik tempel yang dibuat siswa di SDN se-gugus 3 Kecamatan Junrejo Kota Batu merupakan seni murni yang mementingkan nilai keindahannya. Keindahan karya seni rupa teknik tempel terdapat tiga indikator yaitu komposisi warna yang dihasilkan, kerapian dan kebersihan karya seni rupa teknik tempel, dan bidang dasar yang tertutup bahan.

Kemampuan berkarya seni rupa teknik tempel siswa kelas IV di SDN se-gugus 3 Kecamatan Junrejo Kota Batu tergolong baik dilihat dari komposisi warna yang dihasilkan, kerapian dan kebersihan karya seni rupa teknik tempel, dan bidang dasar yang tertutup bahan. Dari temuan penelitian ini, karya seni rupa teknik tempel siswa memiliki warna yang harmonis meskipun tidak semua siswa dapat memadukan warna yang ada pada bahan dan alat pewarna yang dibawa dengan harmonis. Siswa harus pandai dalam memadukan alat pewarna yang dibawa dengan warna bahanbahan yang ada atau memadukan warna-warna bahan antara satu bahan dengan bahan yang lain. 
Penataan bahan-bahan yang ditempelkan pada karya seni rupa teknik tempel dengan rapi membuat karya menjadi lebih bagus. Selain penataan yang rapi, kebersihan karya juga menambah keindahan pada karya seni rupa teknik tempel yang dibuat. Pada karya seni rupa teknik tempel siswa kelas IV di SDN se-gugus 3 Kecamatan Junrejo Kota Batu, kerapian dan kebersihan seni mozaik 69\% dari 112 karya, seni kolase 72\% dari 112 karya, dan seni montase $78 \%$ dari 112 karya. Penilaian aspek sikap apresiatif untuk mengetahui sejauh mana siswa memiliki minat dan penghargaan terhadap nilai keindahan (Sumanto dkk., 2017; S. Sumanto, 2018). Melalui karya siswa dapat dapat diamati aspek kepekaan seni pada siswa misalnya kemampuan menyusun komposisi bahan, kerapian karya, keserasian warna, dan lainnya. Oleh karena itu, salah satu penilaian dari karya siswa yaitu kerapian karya.

Salah satu kriteria berkarya seni rupa teknik tempel yang baik yaitu bidang dasar yang tertutup bahan. Siswa SDN se-gugus 3 Kecamatan Junrejo Kota Batu membuat karya seni mozaik, seni kolase, dan seni montase. Bidang dasar pada karya seni mozaik yang semua bidang dasarnya tertutup dengan bahan terdapat 9 karya (8\%) dari 112 karya dan 103 karya (92\%) yang hanya menutup sebagian besar karya. Hal tersebut tidak sesuai terkait pernyataaan pada penggarapan karya mozaik setiap Tesserae yang ditempelkan haruslah menutup rapat permukaan bidang dasaran agar dapat ditampilkan kesan atau karakteristik yang merupakan keunikan dari karya mozaik tersebut (Sumanto \& Kustiawan, 2011). Berkarya seni mozaik kurang memaksimalkan pemanfaat bidang yang tersedia, yaitu tidak semua bidang diisi dengan bahan, terkesan belum selesai dan terlalu sederhana.

Karya seni kolase yang sebagian besar bidang dasar tertutup dengan bahan terdapat 60 karya (54\%) dari 112 karya dan sebagian kecil bidang dasar yang tertutup dengan bahan terdapat 52 karya $(46 \%)$. Sejalan dengan pernyataan terkati hasil kolase sebagian besar bidang tertutup oleh bahan yang ditempelkan (Destiana, 2018). Sedangkan untuk seni montase yang sebagian besar tertutup dengan bahan terdapat 87 karya $(78 \%)$ dari 112 karya dan sebagian kecil bidang dasar yang tertutup bahan 25 karya. Berkarya seni kolase dan montase sebagian besar sudah memanfaatkan bidang dasar dengan menutup bahan yang tersedia. bahwa kegiatan montase yaitu menempelkan bahan pada suatu bidang sehingga menjadi suatu karya (Rahayu, 2014). Berkarya seni kolase dan montase sebagian besar sudah memanfaatkan bidang dasar dengan menutup bahan yang tersedia.

\section{Faktor Pendukung dan Penghambat Berkarya Seni Rupa Teknik Tempel Siswa Kelas IV}

Temuan faktor pendukung kemampuan siswa kelas IV dalam berkarya seni rupa teknik tempel di SDN se-gugus 3 Kecamatan Junrejo Kota Batu yaitu: (1) faktor siswa yang meliputi bakat dan minat; (2) faktor material/bahan yang meliputi kelengkapan alat dan bahan yang dibawa 
siswa saat berkarya seni rupa teknik tempel; dan (3) faktor lingkungan yang meliputi suasana kelas, kebersihan kelas, dan dukungan orang tua saat di rumah.

Temuan faktor penghambat kemampuan siswa kelas IV dalam berkarya seni rupa teknik tempel di SDN se-gugus 3 Kecamatan Junrejo Kota Batu yaitu: (1) faktor siswa yang meliputi bakat dan minat; (2) faktor material/bahan yang meliputi kelengkapan alat dan bahan yang dibawa siswa saat berkarya seni rupa teknik tempel; dan (3) faktor lingkungan yang meliputi suasana kelas, dan kebersihan kelas, dan dukungan orang tua saat di rumah.

Faktor pendukung berkarya seni rupa teknik tempel siswa kelas IV berasal dari siswa sendiri. Setiap siswa memiliki ketelatenan, kesabaran, dan kreatif yang berbeda dalam membuat pola gambar dalam berkarya seni mozaik dan seni kolase, dan memilih tema atau gambar untuk berkarya seni montase serta memadukan warna. Berdasarkan temuan tersebut, dapat diketahui bahwa bakat yang dimiliki siswa mendukung kemampuan siswa dalam berkarya seni rupa teknik tempel. Bakat sebagai kondisi atau kemampuan yang dimiliki seseorang yang memungkinkannya dengan suatu latihan khusus dapat memperoleh suatu kecakapan, pengetahuan, dan keterampilan khusus (Anggraini dkk., 2020). Dapat disimpulkan bahwa bakat yang dimiliki siswa dalam berkarya seni rupa teknik tempel dapat dilatih agar lebih terampil.

Faktor pendukung berkarya seni rupa teknik tempel siswa kelas IV salah satunya berasal dari material/bahan yaitu kelengkapan alat dan bahan. Saat pembuatan berkarya seni rupa teknik tempel, sebagian besar siswa membawa alat dan bahan masing-masing sehingga siswa fokus dalam berkarya seni rupa teknik tempel. Sejalan dengan pendapat bahwa menyiapkan alat dan bahan sesuai dengan ketentuan, agar kemampuan siswa dalam berkarya tidak terhambat (Cahyono, 2011). Alat yang digunakan dalam berkarya seni rupa teknik tempel seperti gunting, lem, alat pewarna, pensil, dan penghapus. Bahan yang digunakan saat membuat berkarya seni rupa teknik tempel yaitu (1) seni mozaik menggunakan berbagai macam biji-bijian, dan cangkang telur; (2) seni kolase menggunakan daun-daunan kering; dan (3) seni montase menggunakan majalah BoBo.

Suasana kelas yang tenang dan bersih dapat membuat siswa lebih berkonsentrasi dalam berkarya seni rupa teknik tempel. Dukungan orang tua dan guru merupakan salah satu faktor pendukung siswa dalam berkarya seni rupa teknik tempel. Adanya dukungan dari orang tua maupun guru penting bagi siswa dalam menerima hal baru dan siswa lebih percaya diri. Sejalan dengan pernyataan tersebut, dukungan dari orang tua akan membuat anak menjadi lebih giat dalam belajar dan lebih bersemangat (Mahardhika dkk., 2018). Selain itu, guru dapat menentukan sikap agar siswa dapat berwawasan positif dalam perkembangan siswa. Peranan guru juga penting bagi siswa dalam menerima hal baru dan kepercayaan diri yang dimiliki siswa.

Saat pembuatan berkarya seni rupa teknik tempel, beberapa siswa tidak telaten dalam menempelkan bahan sehingga asal menempelkan. Selain itu sebagian siswa juga ada yang 
mengalami kesulitan menemukan ide untuk menggambar pola atau menentukan tema yang akan dipilih, kesulitan menentukan kombinasi warna, kesulitan menggunakan alat, dan kesulitan mengolah bahan. Bakat tidak akan berkembang jika lingkungan tidak memberi kesempatan dan latihan yang baik (Sari \& Suhaili, 2020). Sesuai dengan pernyataan tersebut, meskipun siswa memiliki bakat apabila tidak terasah dengan baik maka tidak akan berkembang pula bakat yang dimiliki, dan tiap siswa memiliki bakat yang berbeda.

Beberapa siswa terlihat ramai dengan temannya dan berkeliling di dalam kelas sehingga siswa tersebut tidak fokus dalam pembuatan berkarya seni rupa teknik tempel. Selain itu siswa merasa cepat bosan dan mengganggap berkarya seni rupa teknik tempel dirasa terlalu rumit. Hal ini terlihat bahwa siswa kurang berminat dalam berkarya seni rupa teknik tempel. Sesuai dengan pernyataan bahwa minat merupakan salah satu faktor yang mempengaruhi perkembangan bakat (Anggraini dkk., 2020). Bakat tidak akan berkembang apabila tidak disertai dengan minat yang cukup tinggi terhadap bidang atau hal yang sesuai dengan bakat.

Saat membuat karya seni rupa teknik tempel, ada siswa yang tidak membawa alat dan bahan seperti lem, alat pewarna, atau bahan yang dibawa sedikit sehingga mereka meminjam atau meminta temannya. Sejalan dengan hal tersebut bahwa kurangnya alat dan bahan yang dibawa dapat menghambat dalam proses berkarya seni (Marsiano dkk., 2019; Permadi, 2015). Ketidaklengkapan alat dan bahan tersebut menyusahkan diri sendiri dan juga temannya.

Suasana kelas yang tidak kondusif membuat beberapa siswa yang tidak bisa fokus dalam berkarya seni rupa teknik tempel. Siswa yang kurang memiliki minat dalam membuat karya seni rupa teknik tempel akan mengganggu teman yang lain dengan cara mengajak temannya mengobrol atau berkeliling di dalam kelas untuk melihat karya temannya sehingga bahan-bahan yang berbentuk kecil bisa berserakan di dalam kelas. Terlebih lagi, teman sebaya dapat memberikan dampak positif maupun negatif dalam proses belajar (Cholifah, 2017). Siswa yang fokus dalam berkarya seni rupa teknik tempel akan merasa terganggu dengan kelas yang ramai dan kelas.

\section{SIMPULAN DAN SARAN}

\section{Simpulan}

Berdasarkan hasil analisis dan pembahasan mengenai kemampuan berkarya seni rupa teknik tempel siswa kelas IV di SDN se-gugus 3 Kecamatan Junrejo Kota Batu, dapat disimpulkan bahwa kemampuan berkarya seni rupa teknik tempel dari 112 siswa di SDN se-gugus 3 Kecamatan Junrejo Kota Batu dalam berkarya seni mozaik, berkarya seni kolase, dan berkarya seni montase termasuk dalam kategori baik secara keseluruhan. Hal ini dilihat dari aspek kreativitas, aspek keterampilan, dan aspek keindahan pada kegiatan berkarya seni tempel. 
Dalam berkarya seni mozaik dan seni kolase siswa sudah dapat menggambar pola sesuai dengan kreativitasnya masing-masing namun beberapa siswa masih kesulitan dalam mencari ide gambar. Pada aspek keterampilan, siswa melakukan proses kegiatan secara mandiri. Pada aspek keindahan, kerapian, dan kebersihan karya seni rupa teknik tempel sudah baik meskipun ada beberapa siswa yang hasil karya seninya kurang rapi dan bersih. Sebagian besar siswa dalam berkarya seni mozaik masih banyak karya yang tidak menutup seluruh bidang dasar dengan bahan, sedangkan untuk seni kolase dan montase siswa sudah menutup sebagian besar bidang dasar dengan bahan namun ada beberapa karya tanpa adanya pewarnaan.

Faktor pendukung dalam berkarya seni rupa teknik tempel siswa kelas IV di SDN se-gugus 3 Kecamatan Junrejo Kota Batu yaitu siswa yang memiliki bakat dan minat, kelengkapan alat dan bahan, dan suasana kelas yang tenang dan bersih. Sedangkan faktor penghambatnya yaitu kurangnya bakat dan minat siswa, ketidaklengkapan bahan yang dibawa, dan suasana kelas yang ramai dan kotor.

\section{Saran}

Berdasarkan kesimpulan telah dipaparkan, diajukan saran-saran bagi pihak yang terkait sebagai berikut. Bagi siswa kelas IV di SDN se-gugus 3 Kecamatan Junrejo Kota Batu. Siswa yang memiliki kesulitan dalam membuat pola gambar dan menentukan tema, disarankan agar siswa dapat mencari pengalaman dari lingkungan sekolah dan lingkungan rumah serta dapat mencari pengalaman tersebut melalui internet. Bagi guru kelas IV di SDN se-gugus 3 Kecamatan Junrejo Kota Batu, guru dapat memberikan arahan dan bimbingan agar siswa memiliki tambahan pengetahuan mengenai teknik dan metode dalam berkarya seni rupa teknik tempel. Bagi SDN segugus 3 Kecamatan Junrejo Kota Batu disarankan dapat menyediakan beberapa alat seperti gunting, lem, crayon atau pensil warna tambahan.

\section{DAFTAR RUJUKAN}

Anggraini, I. A., Utami, W. D., \& Rahma, S. B. (2020). Mengidentifikasi Minat Bakat Siswa Sejak Usia Dini Di SD Adiwiyata. Islamika, 2(1), 161-169.

Bowen, P., Rose, R., \& Pilkington, A. (2017). Mixed methods-theory and practice. Sequential, explanatory approach. International Journal of Quantitative and Qualitative Research Methods, 5(2), 10-27.

Cahyono, F. (2011). Peningkatan Kemampuan Berkarya Seni Grafis Cetak Tinggi Teknik Hardboardcut Melalui Pendekatan Ekspresi-Kreatif Siswa Kelas VIII A SMP Negeri 25 Malang: Malang: Universitas Negeri Malang. Malang: Universitas Negeri Malang.

Cholifah, P. S. (2017). Pemahaman Perspektif Sosial, Penalaran Moral dan Prososial, serta Pengaruh Teman Sebaya pada Siswa Sekolah Dasar. Tarbiyatuna: Kajian Pendidikan Islam, $1(2), 1-11$.

Destiana, D. (2018). Kreasi Kolase Find, Collect, and Fun Together. Cakrawala Dini: Jurnal Pendidikan Anak Usia Dini, 5(2).

Dharsono, S. K., \& Nanang, G. P. (2004). Pengantar Estetika. Bandung: Rekayasa Sains. Bandung. 
Eltanindya, A. Y. (2019). Studi Kemampuan Berkarya Seni Kolase Pada Siswa Kelas IV di SDN Se-gugus 2 Kecamatan Dau Kabupaten Malang. Skripsi tidak diterbitkan, Malang: Fakultas Ilmu Pendidikan Universitas Negeri Malang

Fauzi, M. E., Suryana, D., \& Ismet, S. (2019). Pengaruh Melukis Tarik Benang Terhadap Pekembangan Motorik Halusanak Di Taman Kanak-Kanak Bhayangkari 10 Tanjung Pati Harau. Jurnal Pendidikan Tambusai, 3(3), 1614-1618.

Fauziddin, M. (2018). Meningkatkan Kemampuan Motorik Halus melalui Teknik Mozaik pada Anak Kelompok B di TK Perdana Bangkinang Kota. Journal of Studies in Early Childhood Education (J-SECE), 1(1), 1-12.

Hasnawati, H., \& Anggraini, D. (2016). Mozaiksebagai Sarana Pengembangan Kreativitas Anak Dalam Pembelajaran Seni Rupamenggunakan Metode Pembinaan Kreativitas Dan Keterampilan. Jurnal PGSD: Jurnal Ilmiah Pendidikan Guru Sekolah Dasar, 9(2), 226-235.

Hidayati, N. I. (2014). Pola Asuh Otoriter Orang Tua, Kecerdasan Emosi, dan Kemandirian Anak SD. Persona: Jurnal Psikologi Indonesia, 3(01).

Isnanta, S. D. (2015). Penciptaan Karya Seni Mixed Media Berbasis Ekperimentasi Dengan Teknik Assemblage. Abdi Seni, 6(1).

Jannah, M. (2015). Tugas-tugas perkembangan pada usia kanak-kanak. Gender Equality: International Journal of Child and Gender Studies, 1(2), 87-98.

Kustiawan, U., Kustiawan, K. D. U., Tweet, B. P. D. H. S., Ilmiah, K., Lapangan, K. P. P., Internasional, H., \& Indonesia, G.-R. I. (2018). Pengembangan Materi Pembelajaran Seni Sekolah Dasar. Karya Dosen Fakultas Ilmu Pendidikan UM.

Kustilawati, H. (2013). Pengenalan Teknik Perspektif untuk Peningkatan Hasil Belajar Menggambar Bentuk Geometris di Kelas Vc Sekolah Dasar. Jurnal Penelitian Pendidikan Guru Sekolah Dasar, 1(2), 1-8.

Mahardhika, N. A., Jusuf, J. B. K., \& Priyambada, G. (2018). Dukungan orangtua terhadap motivasi berprestasi siswa SKOI Kalimantan Timur dalam mengikuti pembelajaran pendidikan jasmani. Jurnal Pendidikan Jasmani Indonesia, 14(2), 62-68.

Mardeni, Y. (2019). Pembentukan Karakter Mandiri Melalui Mata Pelajaran Seni Budaya. TRIADIK, 18(2).

Marsiano, E., Nerosti, N., \& Astuti, F. (2019). Faktor-Faktor Penghambat Pembelajaran Seni Budaya (Seni Tari) Di SMP Negeri 4 Padang. Jurnal Sendratasik, 7(4), 11-19.

Kemdikbud. (2018). Peraturan Menteri Pendidikan Dan Kebudayaan Republik Indonesia Nomor 37 Tahun 2018... Tentang Perubahan Atas Peraturan Menteri Pendidikan Dan Kebudayaan.

Munawara, R. (2016). Hubungan Kegiatan Montase dengan Kemampuan Motorik Halus Anak di Kelompok B1 TK Alkhairaat Tondo palu. Bungamputi, 3(1).

Nelson, N., \& Pd, M. (2016). Kreativitas Dan Motivasi Dalam Pembelajaran Seni Lukis. 1, 17.

Permadi, A. (2015). Faktor Pendukung dan Penghambat Media Pembelajaran Seni Budaya di SMPN 1 Tegalsari Banyuwangi. Jurnal Seni Rupa, 3(2).

Putro, R. T. T. (2017). Pengetahuan Dasar Desain Tiga Dimensi Sebagai Cara Mahasiswa Desain Untuk Berpikir Bentuk Ruang Dan Volume. Atrium Jurnal Arsitektur, 3(1), 1-13.

Rahayu, K. (2014). Pembelajaran Seni Kriya Bambu Hias Pada Siswa Kelas VII A SMP N 1 Wadaslintang Kabupaten Wonosobo. Eduarts: Jurnal Pendidikan Seni, 3(1).

Rahayu, S. (2017). Penerapan Kegiatan Montase untuk Meningkatkan Kemampuan Motorik Halus pada Anak Kelompok A di TK Al Wardah Peterongan Jombang. PAUD Teratai, 6(3).

Sääksjärvi, M., \& Gonçalves, M. (2018). Creativity and meaning: Including meaning as a component of creative solutions. AI EDAM, 32(4), 365-379. https://doi.org/10.1017/S0890060418000112

Sari, R. S., \& Suhaili, N. Y. (2020). Bakat Terhadap Motivasi Belajar Siswa Dalam Proses Belajar Dan Pembelajaran. Ensiklopedia of Journal, 2(5), 140-147.

Sumanto, M. S., \& Kustiawan, U. (2011). Kajian Estetika dan Tipologi Gambar Anak Sekolah Dasar di Jawa Timur. Malang: Lemlit UM. 
Sumanto, S. (2018). Seni Keterampilan Anak untuk Meningkatkan Kualitas Pembelajaran bagi Guru. Abdimas Pedagogi: Jurnal Ilmiah Pengabdian kepada Masyarakat, 1(2), 164-170.

Sumanto, S., Gipayana, M., \& Rumidjan, R. (2017). Kerajinan Tangan Di Blitar Sebagai Sumber Belajar Seni Budaya Dan Prakarya (Sbdp) Sekolah Dasar. Sekolah Dasar: Kajian Teori dan Praktik Pendidikan, 24(2), 111-123.

Sumanto, S., Kustiawan, U., \& Sudarmi, S. (2014). Kajian Tema dan Obyek Gambar Anak-anak Sekolah Dasar. Sekolah Dasar, 23(1), 221375.

Sutrisno, M. (2005). Teks-teks kunci estetika: Filsafat seni. Galangpress Group.

Wahana, E. Y. A. A. (2019). Manajemen Penciptaan Karya Seni Rupa (Studi Kasus Tim Produksi Aditya Novali) [PhD Thesis]. ISI Yogyakarta.

Yuningsih, C. R. (2019). Pembelajaran Seni Rupa Di Pendidikan Anak Usia Dini. Jurnal Edukasi Sebelas April, 3(1).

Yustiana, T. (2018). Pemanfaatan Bahan Alam Biji-Bijian Untuk Meningkatkan Keterampilan Membuat Mozaik Dalam Tema Kegiatanku Di Kelas 1 Sekolah Dasar. Jurnal Penelitian Pendidikan Guru Sekolah Dasar, 6(2).

Zaidel, D. W. (2014). Creativity, brain, and art: Biological and neurological considerations. Frontiers in human neuroscience, 8, 389. 